Sign Systems Studies 47(1/2), 2019, 69-87

\title{
Funktionskreis and the stratificational model of semiotic structures: Jakob von Uexküll, Luis Prieto and Louis Hjelmslev
}

\author{
E. Israel Chávez Barreto \\ Department of Semiotics \\ University of Tartu \\ Jakobi 2, 51005 Tartu, Estonia \\ chavezbarretoei@gmail.com
}

\begin{abstract}
The main aim of this article is to show how a possible theoretical articulation between Uexküll's notion of Funktionskreis and the stratificational model of semiotic structures proposed by Louis Hjelmslev can be made. In order to bridge the gap between these two models, Luis Prieto's model of cognition will be used. The advantage of Prieto's model is that it retains the Hjelmslevian stratificational ideas (i.e. a semiotic structure is made up of an expression and a content plane, each one with a dimension of form and substance), while it also pays attention to agency and practice. To put it briefly, according to Prieto the foundation of practice and knowledge is to be found on aisthesis. Hence, as in Uexküll, there is a way to merge action with perception, while retaining the semiotic structure that makes such a merging possible. The key point, however, is that Prieto's model calls for an "ontological commitment" to the substance strata (both in expression and in content to some extent). Therefore, bridging Uexküll and Hjelmslev via Prieto suggests a possible way to provide a general structural model of semiosis which is closer to semiotic realism than to immanentism usually attributed to structuralism.
\end{abstract}

Keywords: functional circle; functional cycle; pertinence; form and substance; expression and content; semiology; umwelt; structuralism; structural semiotics; general semiotics

\section{Introduction}

The aim of the article is to present some preliminary approximations to a general semiotic theory derived from the works of Louis Hjelmslev, Luis Prieto and Jakob von Uexküll. Given the contemporary situation in our field, it seems almost self-evident that a general semiotic theory should be able to give an account of sign systems, and semiosis itself, pertaining to domains that fall well beyond the 
immediate target of the theories developed by Hjelmslev or by Prieto, i.e. a general semiotic theory could not restrict itself to anthroposemiosis. This is not trivial now, as it was not trivial fifty years ago when Sebeok started zoosemiotics, or thirty years ago when biosemiotics began to be developed as a proper branch of semiotics. Conversely, a general semiotics could not be restricted to the immediate object of Uexküll's theorizing, i.e. zoosemiotics, or even, let us assume, biosemiotics. Given that the two theoretical orientations we have chosen concern themselves with two complementary dimensions of the object of study of our discipline (i.e. anthroposemiotics and zoosemiotics), it seems plausible that by bringing them together we could obtain a general theory applicable both to anthroposemiosis, zoosemiosis, and hopefully other realms beyond these two ${ }^{1}$.

In other words, a look at the present state of semiotics leaves no doubt about the importance of biosemiotics as a central branch of the field, especially when it comes to its relationship with general semiotics. Indeed, biosemiotics deserves a very special place within our discipline, for we would expect that the laws discovered by biosemiotics would help us to have a better understanding of semiosis in its minimal stances, e.g. by further developing our minimal models of semiosis, and thus they should be able to contribute in building a comprehensive general theory of semiosis tout court. From this point of view, it would seem almost natural to move towards Uexküll in order to develop Hjelmslev's and Prieto's ideas into an explicitly general theory of semiosis (i.e. a general semiotics). Nevertheless, in order to keep our work rigorous, we will restrict ourselves with just a small aspect of this endeavour. Thus, the present work will have the following four claims (which are strictu sensu formal claims regarding the nature of the possible future theory) as its main axis.

(1) The theoretical articulation between Uexküll and the aforementioned structuralist thinkers can contribute to the elaboration of a general model of semiosis rooted in structuralism.

(2) It is possible to read Uexküll's Funktionskreis ${ }^{2}$ from a Hjelsmelvianoriented point of view, which mainly draws on his stratificational model.

1 By integrating these two models, we would not claim that communicational processes are the same for humans and animals; at most the claim would be that some elementary basic structures of semiosis could hold for both humans and animals. Notice the definition of semiosis and semiosic relations outlined in the following section.

2 Since this Uexküllian notion can be translated both as 'functional cycle' and as 'functional circle', each translation laying some emphasis on different aspects of it (cf. Kull in press where he attributes linearity and automatic execution of operations to 'functional cycle', and simultaneity along with choice between options to 'functional circle'), we would like to keep the original German term and avoid these issues for the moment. 
(3) Within this (Hjelmslevian) structural approach, the notion of pertinence, as posed by Prieto 1975, is necessary for understanding the coupling of perception and action highlighted by Funktionskreis.

(4) Structural models of semiosis (the Hjelsmslevian, the Prietonian and, to some extent, also the Uexküllian one) can be dynamic.

In addition to these four claims, a fifth claim, resulting from the analysis (and thus, in a certain sense, being of a different nature than the previous ones), can be drawn.

(5) There are two ways in which the dynamicity of semiosis can be depicted within this structural framework, namely

(5a) Funktionskreis is a connotative semiotic structure (as defined by Hjelmslev 1943), or

(5b) Funktionskreis presents a double pertinence in the content plane (Prieto 1977[1975]).

Let us start with the exposition of our proposal.

\section{Umwelt as a semiotic structure}

As a first basic assumption, we will follow the idea that semiosic relations are real relations, although their mode of existence is mainly immaterial. A consequence of this first assumption is that semiosic relations are dependent upon a subject ${ }^{3}$. By this second assumption (i.e. semiosic relations are dependent upon a subject), we are inclined to say that semiosic relations are first and foremost mind-dependent relations, but as this might seem too strong a statement, let us simply assume that a necessary (and probably also sufficient) condition for there to be semiosis is the existence of a self ${ }^{4}$, or, to put it in other words, a complex system (i.e. an organism)

3 These two assumptions are present throughout many works within semiotics. The interpretation of umwelt presented by Deely $(2001 \mathrm{a}, 2004)$ in which umwelt can be regarded as objective reality (in the specific sense Deely attributes to "objective") is of main importance. Deely's interpretation of umwelt and its connection to an ontology of relations, which, from our point of view, is a major point for a comprehensive semiotic ontology, is found in Bains 2006.

4 Or subject. Our second assumptions only holds if we deem it necessary for semiosic relations to be actual (thus implying that to be virtually a sign is not enough for something to be a proper sign) and hence that the lower semiotic threshold leaves physiosemiosis out of the scope of semiotic inquiry, because it would be impossible to think about semiosis beyond the realm of the living. Support for this position can be found in Hoffmeyer 2012, Kull et al. 2009, or Kull 2018b. A notable opponent to this position is Deely (2001b, 2014 among other works). A general outline of the discussion can be found, for instance, in Nöth 2001. 
able to establish differences in its extrinsic conditions, and to use those differences actively to preserve-its existence, i.e. what Deacon (2012), for instance, has called teleodynamic organization. The possibility of differentiating, and of recognizing differences as such, results in the fact that, in a very broad sense, semiosic relations can be characterized as relations of interpretation, that is to say, a relation from a teleodynamic system (henceforth: $t$-system) to its extrinsic conditions in which some portions of the extrinsic conditions of the $t$-system are correlated with some portions of the system's phenomenical reality. Thus, $t$-systems will assign phenomenical identities to certain portions of their extrinsic conditions. This is nothing else than another way to characterize umwelt as modelling (see e.g. Kull 2010) - and semiosis as a form of knowing.

The main problem posed by the conceptualization of umwelt as modelling, or mapping, is that of explaining how this mapping is carried out; if an umwelt is indeed a model, and if it correlates the extrinsic conditions of a $t$-system with the phenomenical reality of such $t$-system, then it is possible to posit the existence of a modelling function that maps the set of elements present in the extrinsic conditions into a set of pertinent elements constituting the $t$-system's phenomenical reality. The crux of the matter is thus how to characterize the modelling function that enables umwelt formation? I would like to argue that, at least partially, the answer is to be found in closely considering the notion of Funktionskreis as a process by means of which the umwelt as system is actualized, and generated. This will be explained in the next section.

\section{System and process}

To say that umwelten can be characterized as mapping or modelling amounts to saying that an umwelt is a structure that provides rules, or rule-like processes, for assigning values (i.e. phenomienical identities) to given portions of the environment, thus, in a more precise way, an umwelt would be characterized as a semiotic structure. By 'semiotic structure' we mean an 'entity consisting of internal dependencies' $\left(c f\right.$. Hjelmslev 1959) ${ }^{5}$. Following the Hjelmslevian view, and, in a

5 Hjelmslev's original claim we are paraphrasing reads: "On comprend par linguistique structurale un ensemble de recherches reposant sur une hypothèse selon laquelle il est scientifiquement légitime de decrier le langage comme étant essentiellement une entité autonome de dépendances internes, ou, en un mot, une structure." (Hjelmslev 1959:21). ["By structural linguistics we understand a set of researches relying on a hypothesis according to which it is scientifically valid to describe language as being essentially an autonomous entity of internal dependencies, or in one word, a structure." My translation, I. C.] Trabant (1987), among 
general sense, the structural tradition starting with Saussure to which Hjelmslev belongs, we should readily distinguish between two aspects of a semiotic structure: system and process. This distinction is useful in order to differentiate between the structure as such, i.e. the system, and its actualization in a given instance, i.e. the process. Notice, however, that the dependency between system and process is asymmetrical: the process presupposes the system, but the system does not presupposes the process ${ }^{6}$, which means that the process is not necessary for there to be a system (it is theoretically possible to have a system that never gets actualized in a concrete process), but if there is a concrete process then there is a system enabling its existence. Hjelmslev calls this kind of dependencies 'determinations', i.e. unilateral dependencies in which a term presupposes the other but not vice versa. It is possible to say that, in Hjelmslevian terms, the process determines the system.

others, has shown that it is possible to substitute 'language' by the more general 'semiotic structure', because glossematics is better understood as a general semiotic theory rather than a specifically linguistic theory. When paraphrasing Hjelmslev's claim we decided to leave aside the autonomous part of the claim, since we will follow a more substantialist view in which autonomy of semiotic structures would pose problems. Regarding the term 'semiotic structure', it is important to highlight that it brings Hjelmslev and Prieto close together, due to the fact that Prieto proposed his concept based on Hjelmslev's (Fadda 2003:125).

6 A word should be said about presupposition. On the one hand, it has been signalled by many authors that presupposition is the main relation articulating Hjelmslev's glossematics. Yet as it seems that only Ariza (2012) has made a deep characterization of the Hjelmslevian presupposition, it is very important to take Ariza's characterization into account for it allows us to distinguish between other kinds of presupposition (e.g. as the term is used in pragmatics or semantics). According to Ariza, the Hjelmslevian relation of presupposition can be characterized as follows: given two terms, $\mathrm{A}$ and $\mathrm{B}, \mathrm{B}$ presupposes $\mathrm{A}$ if $\mathrm{B}$ is a sufficient condition for there to be $A$ (every time $B$ is the case, $A$ is also the case, i.e. the presence of $B$ is enough to assure the presence of $A$ ), and $A$ is a necessary condition for there to be $B$ (the presence of $B$ demands the presence of A). He then goes on to say that, thus, what is at play is a seeming reversal of the relationships of antecedence and consequence, because on the one hand: (I) if the NECESSARY antecedent A then the POSSIBLE consequent B, and on the other hand: (II) if the sufficient condition B then the necessary condition A. This can be explained, Ariza claims, because in (I) antecedence and consequence are equalled to logically previous and logically posterior, while (II) is dependent upon the "syntagmatic-functional relations" of the semantics of a conditional. Yet in both cases B presupposes A, and A is presupposed by B. Moreover, presupposition in this sense is not a logical operator but a set predicate, i.e. a relation that generates ordered pairs. Thus presupposition is a relation of order, and has as its properties to be irreflexive, asymmetric and transitive (Ariza 2012). The value of this characterization, it seems to us, goes well beyond clarifying the algebraic foundations of glossematics; to define presupposition in this way (as a relation of order with necessity and sufficiency as rules of correspondence) can throw light on another problems of description that we will try to show in the following sections. 
It is important to bear in mind that the Hjelmslevian model is a model of description; it is a theoretical model in a strong sense, and as such it does not directly concern itself with any kind of metaphysical assumptions. This means that, from a strictly Hjelmslevian point of view, a determination could be nothing more than an epistemic category useful for describing relationships, i.e. dependencies, between parts of a structure ( $c f$. Hjelmslev 1961:39). However, following Prieto 1988 , we can begin to argue for an interpretation of some of the major tenets of Hjelmslev's model from a substantialist $t^{7}$ point of view; namely, a point of view ontologically committed to substance, in the Hjelmslevian sense of the term (Prieto 1975; cf. Badir 2001). This is not at all trivial. Let us put it in this way: a determination is a function established between two functives, a constant and a variable; at the macro structural level, the system is the constant and the process is the variable. On each of the planes of a semiotic structure, the dependencies

7 We call Prieto's point of view a substantialist one based on his own statements: "c'est par la présence et par l'absence d'une même modification des organes sensoriels que se manifestent respectivement, dans l'aisthesis, les caractéristiques composant un couple des caractéristiques corrélatives, et par conséquent, d'un point de vue qui, nous l'admettons volontiers, peut être qualifié de "substantialiste», ce n'est pas n'importe laquelle des caractéristiques composant un tel couple qui en constitue le terme positif ou le terme négatif, celle qui se manifeste par l'absence de la modification des organes sensoriels dont la présence manifeste l'autre constituant bien entendu, de ce point de vue, le terme négatif" ["it is by the presence and by the absence of one and the same modification of the sensorial organs that the characteristics composing a pair of correlative characteristics are manifested in aesthesis, and consequently, from a point of view that we readily admit as "substantialist", it is not any of the characteristics composing such couple the one constituting the positive term or the negative term. The one manifested by the absence of the sensorial organs' modification, whose presence constitutes the other characteristic, constitutes, from this point of view, the negative term."] (Prieto 1975:88; my translation, I. C.). It is nevertheless important to bear in mind that, as Fadda has pointed out: "[...] le materialism [...] de Prieto, [...] se base sur une idée de réalité matérielle, qui existe en soi et indépendamment de la connaissance de l'homme, mais n'a pas d' "essences " qui puissent déterminer a priori la façon dont elle est connaissable." [Prieto's [...] materialism [...] is based upon an idea of a material reality that exists in itself and independently of human knowledge, but which lacks "essences" that could determine a priori the way in which it is knowable.] (Fadda 2013: 7; my translation, I. C.). Throughout this paper, we will refer to this materialist approach as a substantialist stance. Yet it is equally important to notice that even though, as Fadda rightly claims, Prieto's material reality does not consist of essences that determine the knowledge one can have of it, Prieto's materialism does entail constraints on the ways of knowing objects, that Eco (2007: 39), when commenting on Prieto's notion of pertinence, has called impossible pertinences and that, it seems to us, Prieto himself asserts when saying that the negative term in a privative opposition is manifested by an absence of modification in the sensorial organs. Drawing from these considerations, our interpretation of Prieto's substantialist stance will to some extent be more realist than merely materialist. 
between form of content and substance of content, and form of expression and substance of expression, are also determinations in which form is the constant and substance is the variable. Thus, substance can be defined in Hjelmslevian terms as "the variable in a manifestation" 8 . If one were to make an ontological commitment to substance, this would seemingly mean making an ontological commitment to what should be somewhat ontologically undetermined. Prieto's susbtantialist stance, however, commits to the materiality of substance regarding its "determined" aspects from the point of view of form. In other words, Prieto's substantialist stance seeks to find material correlates, in substance, of the pertinent features established by form. Yet, the substantialist stance does not necessarily mean making substance ontologically determined, inasmuch form is, to some degree, arbitrary (or, to use a less controversial term, dependent upon a point of view).

Taken to its last consequences, the substantialist stance could result in reversing Hjelmslev's claim that "a system [...] governs and determines [the process] in its possible development" (Hjelmslev 1961: 39). The substantialist stance would ultimately force us to admit that even though granting that the process presupposes the system, the process shapes the system by means of actual practices. Indeed, one could say Hjelmslev (1954: 171) was already aware of this possible interpretation when he wrote:

la détermination (fonction unilatérale entre la substance comme variable et la forme comme constante) n'est valable que du seul point de vue syntagmatique (comme un sélection), tandis que du point de vue paradigmatique il ya réciprocité (plus particulièrement: complémentarité) entre forme et substance, la substance ne peut jouer le rôle d'une variable que dans les cas nets où par l'analyse immédiate le syntagmatique est seul en cas. ${ }^{9}$

A syntagmatic is a semiotic process (Hjelmslev 1961: 135), and as a process it is relational in Hjelmslev's sense of the term, which is to say it is a function of the type "both... and.... A paradigmatic, on the other hand, is a semiotic

8 A manifestation is both a selection, i.e. a type of determination, between system and process, and the specific relationship between form and substance (Hjelsmlev 1954: 166). A discussion of manifestation in similar terms to the ones we are discussing can be found in Siertsema 1965: 126-129.

9 "The determination (unilateral function between the substance as variable and the form as constant) is only valid from the syntagmatic point of view (as a selection), while from the paradigmatic point of view there is reciprocity (more specifically: complementariness) between form and substance; substance cannot play the role of a variable but in the specific cases in which, for the immediate analysis, the syntagmatic is the case." (My translation, I. C.) 
system, and as such it is correlational, again in Hjelmslev's sense of the term; it is a function of the type "either... or...". Thus, only in the process is it valid to characterize the relationship between form and substance as a determination. In the system, however, it appears as complementariness ${ }^{10}$. The decisive step taken by the substantialist stance consists in granting an ontological foundation to a type of relation included by Hjelmslev's descriptive model (i.e. the Hjelmslevian determination, especially as manifestation).

Coming back to the main problem we are addressing, mainly that of conceptualizing umwelt as modelling and explaining how such a model is carried out, we can begin to draw some corollaries:

(i) If a $t$-system can generate an umwelt, and the umwelt in question is a semiotic structure, then umwelt could be considered both as a syntagmatic (process) and as a paradigmatic (system).

(ii) The paradigmatic dimension of umwelt would be presupposed by the syntagmatic dimension of it, yet the syntagmatic dimension would shape the paradigmatic one by means of actual practices.

(iii) The syntagmatic aspect of umwelt is Funktionskreis.

(iv) Since an umwelt comprises both Merkwelt and Wirkwelt, these two aspects are to be included both in each dimension of the umwelt, i.e. the paradigmatic (the umwelt as system), and the syntagmatic (Funktionskreis as process).

(v) Each dimension of an umwelt has two planes (a Merk-plane, and a Wirkplane). If we characterize these planes as Hjelmslevian planes (after Hjelmslev 1954), each of them would comprise a stratum of form and a stratum of substance.

(vi) In the syntagmatic, i.e. Funktionskreis there is a Hjelmslevian determination between form and substance.

(vii) After Prieto's substantialist stance, substance imposes material correlates to form, thus process shapes system, and thus Funktionskreis as process shapes umwelt as system.

Nevertheless it is important to notice that even if one decides to follow the substantialist stance, substance still presupposes form. Form is only established by a principle of pertinence, as a principle of pertinence is necessary for making and recognizing differences in substance. If a given element in the extrinsic conditions

10 Indeed, it is possible to read the syntagmatic function, "both... and...", as intersection between classes, and the paradigmatic function, "either... or...", as union between classes. A syntagmatic would then refer to simultaneity of facts or, to put it in other words, to the cooccurrence, hic et nunc, of a chain of facts (the chain being somewhat conceptualized as an intersection between classes of facts, $c f$. Prieto 1977: 209). On the other hand, a paradigmatic would consist in all the possible facts pertaining to each of the classes present in a syntagmatic. 
of a $t$-system can be recognized by the $t$-system, this is only because the pertinence principle logically precedes the act of recognition, and thus substance is dependent upon form; for there to be an object that is recognizable, form must have been established previously. The substantialist stance only claims that the features of substance can influence and shape form, thus resulting in the fact that form is not independent of substance (as substance is not independent of form - after all, there is paradigmatic complementariness between them). Ultimately, what the substantialist stance is claiming is that neither form can be reduced to a systemic aspect, nor can substance be reduced to a material aspect. To put it in other words, knowing arises at the meeting of semiotic structure and material reality.

\section{Practice}

Contrary to the standard reading of Uexküll, according to which the umwelt is mainly the subjective world, our aim is to characterize umwelt from the point of view of a semiotic realism in which umwelt cannot be reduced to the phenomenical, nor to affordances in the surroundings. It is thus not arbitrary that we have chosen to conceptualize umwelt formation as modelling. Indeed, according to Ivanov (1962: 201), a model is a "form that reflects an object, and it is composed by a finite numbers of elements plus the relations between those elements". Such elements, and their relations, must be present in the modelled object, but they are only recognized as present in the modelled object inasmuch they carry pragmatic value ( $c f$. Ivanov 1962: 201). In other words, the depiction in the model of the modelled object is tied to the pragmatic relevance of the features borne by the modelled object; a model will substitute an object with respect to certain aspects of such object, i.e. there is a productive way in which a model substitutes an object (cf. Lotman 2011[1967]: 251).

The substantialist stance we presented in the previous section can be related to Ivanov's notion of model. Indeed, retaining in the model the features of the modelled object that carry pragmatic value can be interpreted as correlating a set of form-features in the model with a set of substance-features present in the modelled object. The notion of pragmatic value is a key element for bringing these positions together. Following Prieto, knowledge about material reality is always directed towards a way of acting upon the material reality that is being known; knowledge, he claims, always involve a practice (Prieto 1977[1975]: 151).

Moreover, a practice, following Prieto 1987, always involves the ability to choose between executing a transformation which causes the practice, or not executing the transformation; i.e. a practice presupposes a faculty of decision. 
This conclusion has also been reached in biosemiotics, for instance, in Kull 2018b, or the opening remark in Kull 2018a: 383: "Semiosis assumes choice - even if the organism is not aware of it. For instance, a dog who starts barking is not an automaton - at least during a brief moment it can (subconsciously) choose either to do so or not". Looking at Prieto's theory from a biosemiotic point of view, we could say the dog executes a practice ${ }^{11}$. However, Prieto himself would probably disagree with the idea of the dog performing a practice in the outlined sense, since he states (Prieto 1987: j10) that only humans, who are conscious of the numeric identity of their own body, can be properly called subjects and thus have a faculty of decision ${ }^{12}$. In order to interpret Prieto's position as founding a general theory of semiosis, we would have to accept that a subject's conscious awareness of the numeric identity of his own body is not a necessary condition for endowing the subject with a faculty of decision; the concept of decision, and hence the concept of practice in Prieto would have to be read in a more general sense.

In any case, let us assume that this widening of Prieto's concept is possible, and that to know an object means to make it perform a determined role (as means or as ends) in a given practice. In its turn the practice is founded upon a criterion of pertinence derived from the semiotic structure by means of which a subject knows (or cognizes) material reality. Taking into account everything that has been said up to here, if we assume that Funktionskreis is a practice, then

(viii) Funktionskreis presupposes a criterion of pertinence (and an umwelt as model will retain the relevant pragmatic aspects of the modelled objects);

(ix) Funktionskreis presupposes a semiotic structure; and

(x) Funktionskreis presupposes a faculty of decision.

11 It would be necessary to specify which kind of objects are at play in such a practice. To make a tool out of a stone is a practice that has a material object as its end (i.e. the tool being produced); a speech act, or as Prieto would say, a semic act, is a practice that has a non-material object as its outcome, i.e. the sense, or the message, that is being conveyed by the speech act, and that is also using as means an object different in some regards to the object used as means in a practice such as making a tool out of a stone (cf. Prieto 1976: 165-167, 1987, and specially Prieto 1997 for the distinction between material and symbolic practices). The pertinence of the features borne by the objects in each practice would be different to some extent, as material objects have "intrinsic" qualities which render them pertinent from the point of view of a given practice (cf. Prieto 1976: 167).

12 This problem has been discussed in depth in Fadda 2007. 


\section{Prieto's model of cognition}

We have said that a practice is founded upon a criterion of pertinence provided by the semiotic structure by means of which a subject knows material reality. In a response to Burger's review of Pertinence et pratique, Prieto (1976: 167) defines pertinence in the following way:

La "pertinence» est pour moi la qualité de ce qui est pertinent, et "pertinent» est, dans mon usage technique, ce que l'on dit d'une caractéristique d'un objet qui est reconnue par un sujet et qui compte donc pour l'identité sous laquelle ce sujet connaît l'objet en question. Si parfois je parle pourtant comme si j’identifiais pertinence et point de vue, c'est parce que la pertinence des caractéristiques pertinentes d'un objet est toujours la conséquence d'un point de vue duquel le sujet considère cet objet. Ce point de vue est toujours celui d'une pratique exercée par le sujet [...]. ${ }^{13}$

In Pertinence et Pratique, as well as in his entry on "Relevance" written for Sebeok's Encyclopedic Dictionary of Semiotics (Prieto 1994), Prieto also defines pertinence as a relationship of equivalence among the objects that can be used by a subject either as means or ends of a practice (Prieto 1975: 101, 1994). Pertinence as a relation of equivalence is established by classification systems. Prieto's concept of classification system is derived from the notion of characteristic (or feature, I will use these two terms interchangeably) and the notion of difference. Indeed, Prieto claims that to recognize a characteristic in an object entails the recognition of differences in other objects, even if these differences are only virtually recognized (cf. Prieto 1975: 82-83, 99). He writes,

Le calcul que suppose le fait de reconnaître qu'un objet comporte une ou plusieurs caractéristiques et qu'il diffère par conséquent d'autres objets est donc le calcul de deux ou plusieurs classes auxquelles peut appartenir cet objet ou, plus exactement, puisque ces classes sont toujours en rapport logique d'exclusion entre elles et que leur somme logique est par définition égale à l'univers du discours, le calcul de ce quon appelle un système de classement. (Prieto 1975: 98) ${ }^{14}$

13 'Pertinence is, for me, the quality of being pertinent, and 'pertinent', in my technical usage, is said of an object's characteristic which is recognized by a subject and which counts for the identity under which the subject knows [or cognizes - I. C.] the given object. If therefore at times I speak as if equating pertinence and point of view, it is because the pertinence of the pertinent characteristics of an object is always the consequence of a point of view from which the subject considers such object. This point of view is always that of a practice executed by the subject [...]" (my translation, I. C.).

14 "The calculus that is implied by the fact of recognizing that an object bears one or more characteristics and that consequently the object differs from another objects is the calculus of two or more classes to which the object can belong to, or more exactly, and because these classes 
Thus, a totality of objects, that Prieto calls a universe of discourse, is classified (or ordered) via pertinence as relations of equivalence. A class thus would be established by equivalences among objects, with two mutually exclusive classes being the minimal classification system, e.g. class A and its complement. Notice that if a classification system is a calculated then the virtual recognition of the objects that would be members of the complementary class is possible. Indeed, Prieto posits a crucial distinction between virtual knowledge and actual knowledge. Actual knowledge is the confirmation, hic et nunc, that this specific object is a member of a specific class. A cognitive act, according to Prieto (1975: $115)$, can only be actual. ${ }^{15}$

Regarding the recognition of the characteristics borne by the object, Prieto (1975: 88) writes that " $[u] n$ objet napparaît pas comme tel, c'est-à-dire comme ne se confondant pas avec le néant tant que le sujet ne reconnaît pas, dans l'aisthesis de la portion de la réalité qui le constitue, la présence d'une modification déterminée des organs sensoriels" ${ }^{16}$ Furthermore, he says that the absence of modifications in the sensorial organs amounts to a negative characteristic, i.e. the term defined as 'absence' in a privative opposition.

The previous statements come together in the entry "Relevance" in which he writes in a somewhat Kantian fashion,

The perception of an object by a subject is always achieved through a concept, which can of course be either explicit or implicit, that is to say that the subject is not necessarily able to detail the features which constitute it. To perceive an object

are always in a logic relation of exclusion between them and their logic sum is by definition equal to the universe of discourse, it is the calculus of what we call a classification system" (my translation, I. C.).

15 Prieto (1975: 99) originally wrote, in French, 'connaisance actuelle' and 'connaissnace virtuelle. It seems possible to use the English word 'actual' when translating 'actuelle' because of two main reasons: (i) when discussing these two types of knowledge, Prieto specifies that the recognition of characteristics entails, first, the calculus of classification systems and, second, determining which one among the possibilities calculated by a classification system is really (effectivement) taking place (Prieto 1975: 99); (ii) in determining the possibility that is really taking place Prieto talks of verification ('constatation' in the original French text); he writes: "un acte cognitive intervient chaque fois qu'un sujet constate [my emphasis, I. C.] l'appartenance d'un objet à une des classes composant un système de classement notatif' ["a cognitive act takes place every time a subject verifies the membership of an object to one of the classes composing a notative classification system."] (Prieto 1975: 115; my translation, I. C.).

16 "An object does not appear as such, that is to say as not being confused with nothingness inasmuch the subject does not recognize, in the aesthesis of the portion of reality that constitutes the object, the presence of a determined modification of the sensorial organs" (my translation, I. C.). 
is, in other words, nothing but to recognize it as the realization of a concept and therefore to recognize in it those features, and as a rule only those of its features, that constitute this concept. (Prieto 1994: 794)

Following Prieto, then, a characteristic entails a difference, and a characteristic is recognized in aesthesis. To know an object is to recognize it as a member of a class of objects involved in a given practice. In order to recognize that an object is a member of a class, some of its features need to render the object equivalent to other objects bearing the same, or mostly the same, features. The recognition of these features as actual features borne by the object is achieved through an actual confirmation (schematized as: THIS object belongs to class A, and differs from SOME OTHER object, $c f$. Prieto 1975: 100). The actual confirmation of the fact that an object bears a given feature is achieved through the aesthesis of the portion of reality that the object constitutes. In aesthesis the object manifests its features exerting modifications upon the sensorial organs of the subject. Thus a cognitive act starts in sense perception.

\section{Planes and stratification}

We have seen that, according to Prieto's model of cognition, it is by means of modifications in the sensorial organs that an object appears properly as an object to a subject. In a communicational act, the listener interprets a given utterance by assigning phenomenical identities to the string of sounds (thus in-forming the acoustic substance). These phenomenical identities are dependent upon a given classification system. However, phenomenical identities of sounds are dependent upon yet another classification system that determines what can be said by means of the phenomenical identities of sounds. These two classification systems are the two planes constituting a semiotic structure (i.e. an expression plane of signifiers and a content plane of signifieds). However, this is not exclusive of linguistic systems. A tool can be thought of as a bifacial entity as well (Prieto 1975: 64). Indeed, following Prieto, to operate with two classification systems constituting two planes that furnish pertinence to each other (i.e. to operate with semiotic structures) is a property of the very act of knowing.

In corollaries (vi) and (v) of Section 3, we have characterized umwelt as a semiotic structure. Umwelt would then consist of two planes, characterized as Hjelmslevian planes and thus having strata of form and substance. This amounts to characterizing umwelt in correspondence with Fig. 1 


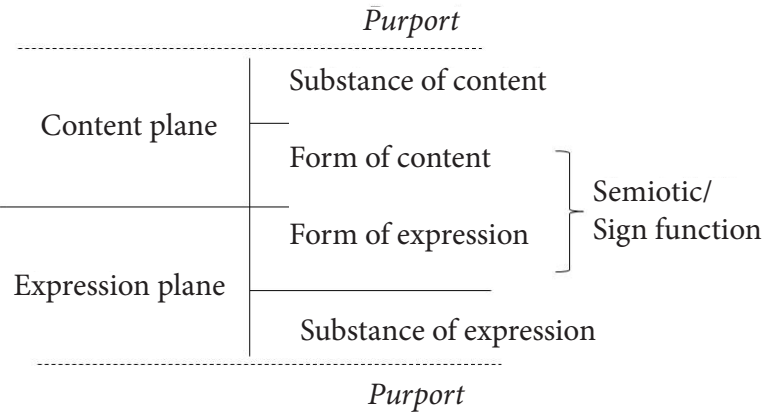

Figure 1. The stratificational model of a semiotic structure (after Hjelmslev 1954).

Corollary (v) posited the existence of a Wirk-plane and a Merk-plane. It seems possible to equate Wirkwelt with the content plane and Merkwelt with the expression plane, since the Merkplane would assign phenomenical identities to perceivable objects (Uexkull 2010: 47-49). On the other hand, given that Merkzeichen would elicit a determined response, the Wirkwelt could be characterized as the content plane.

Furthermore, Prieto posits a difference between the classification systems pertaining to each of the planes. The classification system that establishes the classes constituting the expression plane is a notative classification system, as it does not supposes any other classification of the elements of the expression plane. On the contrary, the classification system that establishes the classes of the content plane is defined as a connotative classification system because it supposes at least another classification of the elements of the content plane (Prieto 1975: 108). The fact that one can use a knife both for cutting and as a screwdriver is explained by the fact that there is a classification system establishing the utility of a knife and a classification system establishing the operations that can be executed by means of a knife ( $c f$. Prieto 1975: 109). The knife as such is given only one identity, i.e. it is known by a notative classification system.

To explain things in a clearer way, let us consider the well-known example of the tick's Funktionskreis presented in Uexküll (2010: 50). In the tick's Funktionskreis, the mammal's skin glands function as feature carriers (Merkmal), they are then recognized as proper perception signs (Merkzeichen) and correlated with the possibility of performing a practice, namely 'release legs'.

The smell of butyric acid common to all mammals is a form-feature in the tick's umwelt. Let us use ' ....' to denote elements of form and '[...]' to denote elements of substance on each plane. We can then write /butyric acid/ to refer to its smell as perceived by the tick, i.e. as an element of form (and, conversely, [butyric acid] as an element of substance). The feature +/butyric acid/ would establish relations 
of equivalences among multiple objects in the tick's environment (Uexküll 2010: 179). This Merk-plane would then have a classification system consisting in two classes; namely +/butyric acid/, and -/butyric acid/. It seems plausible to think that this classification system would not suppose another classification referred to the elements in this plane, and thus we could consider it as the expression plane. On the other hand, regarding the content plane, a naïve way of putting the Funktionskreis into the stratificational model, would have to decide between two options: is the content plane constituted by the mammal as perceived by the tick (as in Fig. 2A) or by the activity 'release legs' (as in Fig. 2B)?

A

Content $\frac{/ \text { mammal/ }}{\text { Expression }}$

B

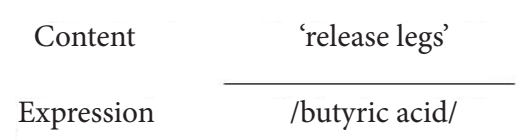

Figure 2. Two naïve ways of representing Funktionskreis as a semiotic structure.

The models in Fig. 2 miss the point of coupling action with perception; therefore, it is necessary to include the two aspects constituting the content plane into one single structure. As we stated in claim (5) at the beginning of the article, there are two possibilities of doing this. The first possibility is to posit that Funktionskreis is best explainable as a connotative structure (as in Hjelsmlev 1961), Fig. 3 illustrates this possibility.

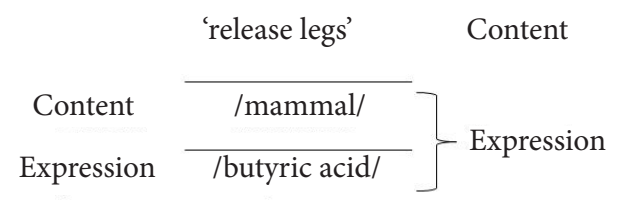

Figure 3. Funktionskreis as a connotative structure.

To posit that Funktionskreis is explainable as a connotative structure amounts to saying that there are two signs at play. First, there is a complete sign made up by /butyric acid/ on the expression plane and /mammal/ on the content plane. This complete sign will in its turn function as the expression plane for another sign which would have 'release legs' as its content plane, by virtue of /mammal/ functioning as an indicator for the activity 'release legs'. 
The second possibility of explaining Funktionskreis as a semiotic structure would simplify the structure of the sign, it would posit the existence of only one sign, but it would make the semiotic structure itself more complex. This other possibility consists in endowing Funktionskreis with a double pertinence on the content plane, thus implying that two classification systems are at play simultaneously. This alternative possibility is illustrated in Fig. 4.

\begin{tabular}{lc} 
Content C & 'release legs' \\
Content N & /mammal/ \\
\cline { 2 - 2 } Expression & /butyric acid/
\end{tabular}

Figure 4. Funktionskreis as double pertinence on the content plane. Content $\mathrm{C}=$ connotative classification system on the content plane. Content $\mathrm{N}=$ notative classification system on the content plane.

According to this possibility, the expression plane would be constituted solely by /butyric acid/. The double pertinence on the content plane would pose a notative classification system on the content plane correlating /mammal/ with /butyric acid/, and a connotative classification system also on the content plane correlating /mammal/ with the possibility of executing the activity 'release legs'.

The fact that the Wirk-plane refers both to /mammal/ and to the activity 'release legs' supports the idea that the Wirk-plane can be taken as the content plane, since there are two classification systems at play, a notative classification system establishing classes of objects and a connotative classification system establishing classes of activities. Thus, via the notative classification system in the Wirk-plane, there is a correlation established between /butyric acid/ and $/ \mathrm{mammal} /$. The connotative classification system, which is connotative in relation to the first notative system in the Wirk-plane, would establish the correlation between /mammal/ and 'release legs'. In addition, [mammal], i.e. the mammal as substance would be not immediately graspable by the tick, it would certainly influence the establishment of /mammal/ as form element, but it would constitute a different stratum and thus the Uexküll's notion of 'counterstructure' (Gegenfüge) would correspond to substance as matter. 


\section{Conclusions}

To decide between the two options, Funtionskreis as a connotative structure or Funktionskreis as exhibiting a double pertinence on the content plane would call for weighing the advantages of each model against proper descriptive work.

In any case, the conceptualization of Funktionskreis as a semiotic structure, and furthermore as a syntagmatic, can contribute to explaining how codes are established, for indeed by assuming, on the one hand, that Funktionskreis presupposes a faculty of decision, and, on the other hand, that Funktionskreis is a process and thus it can shape the system it ultimately produces, it is possible to reach the conclusion that practices might beget habits and semiosis might beget codes. The main problem of this proposal lies in how to characterize a subject capable of semiosis and what it actually means to have a faculty of decision. It is at this point that the approaches at play divide. This difference, however, does not seem to be impossible to overcome. From the point of view of a general semiotics, the basic and general mechanisms of semiosis should remain mostly the same throughout different meaning-making processes. The differences at the level of explanatory models would be rendered less relevant than their similarities. ${ }^{17}$

\section{References}

Ariza, Miguel 2012. Hacia un modelo presuposicional de semiótica algebráica. Tonos Digital 22. Badir, Semir 2001. La sémiologie selon Luis J. Prieto. Linx 44: 55-73.

Bains, Paul 2006. The Primacy of Semiosis: An Ontology of Relations. Toronto: University of Toronto Press.

Deacon, Terrence 2012. Incomplete Nature: How Mind Emerged from Matter. New York: Norton \& Co.

Deely, John 2001a. Umwelt. Semiotica 134(1/4): 125-135.

- 2001b. Physiosemiosis in the semiotic spiral: A play of musement. Sign Systems Studies 29(1): 27-48.

- 2004. Semiotics and Jakob von Uexküll's concept of umwelt. Sign Systems Studies 32(1/2): 11-34.

- 2014. Physiosemiosis as an influence of signs. How would semiosis precede life? Chinese Semiotic Studies 10(3): 375-407.

17 Acknowledgements: I would like to thank Riin Magnus for her comments on earlier drafts of this article, Silvi Salupere for her comments and discussions, which helped me to improve some parts of this paper, and Kalevi Kull for his encouragement, advice and discussions during the elaboration of this text. Special acknowledgement goes to the reviewer of this paper, whose comments helped me to improve the clarity of my argumentation, and to the editors of this journal for the efforts they took in making my text clearer. I am deeply indebted to my dear friend Miguel Ariza for all our conversations on the topics treated in this paper. 
Eco, Umberto 2007. La pertinence de Luis Prieto. Cahiers Ferdinand de Saussure 60: 35-40.

Fadda, Emanuele 2003. Laggettivo 'semiotico': Note sulla lettura di Hjelmslev da parte di Luis Prieto. Janus 3: 121-136.

- 2007. L'identité symbolique: Notes sur le sujet de la sémiose chez Prieto. Cahiers Ferdinand de Saussure 60: 73-84.

- 2012. Luis J. Prieto: uno strutturalista "analitico"? Versus 115: 25-40.

- 2013. L. J. Prieto ou le dernier sémiologue structurel. Presentation at the 19th International Congress of Linguists.

Hjelmslev, Louis T. 1954. La stratification du langage. Word 10(2/3): 163-188.

- 1959. Linguistique structurelle. Essais Linguistiques (Travaux du Cercle Linguistique de Copenhague 12). Copenhague: Det Berlingske Bogtrykkeri, 21-26.

- 1961[1943]. Prolegomena to a Theory of Language. Wisconsin: University of Wisconsin Press.

Hoffmeyer, Jesper 2012. The natural history of intentionality. In: Schilhab, Theresa; Stjernfelt, Frederik; Deacon, Terrence (eds.), The Symbolic Species Evolved. (Biosemiotics 6.) Dordrecht: Springer, 97-116.

Ivanov, Vyacheslav V. 1962. The science of semiotics. New Literary History 9(2): 199-204.

Kull, Kalevi 2010. Umwelt and modelling. In: Cobley, Paul (ed.), The Routledge Companion to Semiotics. London: Routledge, 43-56.

- 2018a. A study by Umberto Eco and his colleagues on the history of early zoosemiotics: Commentary and bibliography. Sign Systems Studies 46(2/3): 383-391.

- 2018b. Choosing and learning: Semiosis means choice. Sign Systems Studies 46(4): 452-466.

- in press. Jakob von Uexküll and the study of primary meaning-making.

Kull, Kalevi; Deacon, Terrence; Emmeche, Claus; Hoffmeyer, Jesper; Stjernfelt, Frederick 2009. Theses on biosemiotics: Prolegomena to a theoretical biology. Biological Theory 4(2): 167173.

Lotman, Juri 2011[1967]. The place of art among other modeling systems. Sign Systems Studies 39(2/4): 249-270.

Nöth, Winfried 2001. Protosemiotics and physicosemiosis. Sign Systems Studies 29(1): 13-27.

Prieto, Luis Jorge 1975. Pertinence et Pratique: essaie de sémiologie. Paris: Les Éditions De Minuit.

- 1976. Réponse de Luis J. Prieto Cahiers Ferdinand de Saussure 30: 165-175.

- 1977[1975]. Estudios de Lingüística y Semiología generales. México: Nueva Visión.

- 1987. Une Sémiologie: Problèmes et parcours. Dégres 49/50: j1-j12.

- 1988. Caractéristique et dimension. Cahiers Ferdinand de Saussure 42: 25-63.

- 1994[1986]. Relevance. In: Sebeok, Thomas A. (ed.), Encyclopedic Dictionary of Semiotics. (2nd ed.) Berlin: Walter de Gruyter, 794-795.

- 1997. Entre signal et indice: l'image photographique et l'image cinematrográphique. Cahiers Ferdinand de Saussure 50: 21-43.

Siertsema, Bertha 1965. A Study of Glossematics: Critical Survey of its Fundamental Concepts. The Hague: Martinus Nijhoff.

Trabant, Jürgen 1987. Louis Hjelmslev: glossematics as general semiotics. In: Krampen, Martin; Oehler, Klaus; Posner, Roland; Sebeok, Thomas; Uexküll, Thure von (eds.), Classics of Semiotics. New York: Springer, 89-108.

Uexküll, Jakob von 2010[1961]. A Foray into the Worlds of Animals and Humans (with A Theory of Meaning). (O’Neil, Joseph D., trans.) Minnesota: University of Minnesota Press. 


\section{Funktionskreis и стратификационная модель семиотических структур: Якоб фон Икскюль, Луис Прието и Луи Ельмслев}

Основная цель этой статьи - показать возможность теоретической артикуляции связи между функциональным кругом Икскюля и предложенной Луи Ельмслевом стратификационной модели семиотических структур. Для соединения этих двух моделей используется когнитивная модель Луиса Прието. Преимущество модели Прието состоит в том, что она сохраняет стратификационные идеи Ельмслева (т.е. семиотическая структура составлена из планов выражения и содержания с дальнейшим различением в них формы и субстанции), в то же время уделяя внимание деятельности и практике. Основа практики и знания заключается по Прието в эстезисе (aisthesis), что делает возможным (как и в случае Икскюля) соединить действие и восприятие, сохраняя семиотическую структуру. Ключевым моментом, однако, является то, что модель Прието требует “онтологической приверженности” субстанции (как в плане выражения, так и - в меньшей степени - в плане содержания). Поэтому соединение Икскюля и Ельмслева через Прието дает возможность предложить общую структурную модель семиозиса, которая ближе к семиотическому реализму, чем к имманентизму, обычно приписываемому структурализму.

\section{Funktionskreis ja semiootiliste struktuuride stratifikatsiooniline mudel: Jakob von Uexküll, Luis Prieto ja Louis Hjelmslev}

Artikli peamine eesmärk on näidata, kuidas on võimalik teoreetiliselt sõnastada kokkupuudet Uexkülli Funktionskreis'i mõiste ning Louis Hjelmslevi poolt välja pakutud semiootiliste struktuuride stratifikatsioonilise mudeli vahel. Nende kahe mudeli ühendamiseks kasutatakse Luis Prieto kognitsioonimudelit. Prieto mudeli eeliseks on see, et selles säilitatakse hjelmslevlikud stratifikatsiooniideed (s.t semiootiline struktuur koosneb väljendus- ja sisuplaanist, millest kummalgi on vormi ja substantsi mõõde), pöörates samas tähelepanu ka agentsusele ja praktikale. Lühidalt väljendudes peitub praktika ja teadmise alus Prieto järgi esteesis (aisthesis). Seega, nagu ka Uexkülli puhul, on võimalik tegutsemist tajumisega ühte liita, säilitades semiootilise struktuuri, mis muudab sellise liitumise võimalikuks. Olulisim on aga see, et Prieto mudel kutsub üles "ontoloogiliselt pühenduma" substantsikihtidele (nii väljenduses kui teatud määral ka sisus). Seetõttu annab Uexkülli ja Hjelmslevi ühendamine Prietot kasutades võimaluse pakkuda välja semioosi strukturaalne üldmudel, mis on lähemal semiootilisele realismile kui strukturalismile tavaliselt omistatavale immanentismile. 